\title{
Moderating effect of perceived risk on the relationship between product safety and intention
}

\author{
Sarina Ismail ${ }^{\mathrm{a}^{*}}$ and Sany Sanuri Mohd Mokhtar ${ }^{\mathrm{b}}$
}

${ }^{a}$ Othman Yeop Abdullah Graduate School of Business, Universiti Utara Malaysia, Sintok, Malaysia ${ }^{b}$ School of Business Management, Universiti Utara Malaysia, Sintok, Malaysia

\begin{tabular}{l}
\hline C H R O N I C L E \\
\hline Article history: \\
Received September 28, 2014 \\
Accepted 28 December 2014 \\
Available online \\
December 282014 \\
\hline Keywords: \\
Buying intention \\
Actual buying \\
Product safety \\
Perceived risk \\
Herbal product \\
Consumer behavior \\
Malaysia
\end{tabular}
A B S T R A C T

Herbal Products industry has experienced significant growth in product demand. Therefore, this study aims to identify the factors effecting the actual buying of Herbal Product. This study also examines the moderation effect of perceived risk on the relationship between product safety and intention. Mall intercept survey was used to collect data from six various states in Malaysia. The data is analyzed using Partial Least Squares (PLS) path modeling. The path coefficient results supported the direct influence of intention on actual buying. Similarly, the findings reveal that perceived risk moderate the relationship between product safety and buying intention.

\section{Introduction}

The global demand on herbal products have increased due to the worldwide awareness and preferred trend for natural alternatives to synthetic products (Abdullah \& Salleh, 2010; Jamal, 2006; Karim et al., 2011). Herbal products have also been associated with health care solutions in treating and preventing various diseases. For instance, it has been reported that herbal products are used to relieve symptoms related with HIV/AIDS. (WHO, 2011). There are several factors that contribute to these phenomena's (Raghavendra, 2009; Saokaew, 2011) namely;

1) Inefficient conventional medicine that result of side effects and other problems,

2) Accessibility of conventional medicine,

3) Perception of the herbal product i.e. harmless,

4) Desire for self-medication, and,

5) Cheaper costs.

*Corresponding author.

E-mail addresses: isarina4@gmail.com (S. Ismail)

C 2015 Growing Science Ltd. All rights reserved. doi: $10.5267 /$ j.msl.2014.12.016 
However, there is a disagreement in a study, which was carried out by Astin and Pal (1998). The authors found that herbal products could be used as an alternative; not because they are against the conventional medicine, but it is has been part of cultural values, attitudes, motivation and belief (Hassali et al., 2009). Ironically, though the use of herbal products is increasing, the safety issues and the global adverse effect also found to be increasing (Boullata \& Nace, 2000). The safety of herbal products is very important because most of the products in use are for self-medication (Zaffani et al., 2006). Commonly, the use of herbal products appears to be safe but not necessarily without adverse effect, it also can cause serious adverse effects (Bent, 2008; Bouldin et al., 1999; Sahoo, Manchikanti, \& Dey, 2010). Adverse effect occurs due to the existence of poison found in herbal plants, pollution, and poor manufacturing practice (Balammal et al., 2012; Saad et al., 2006).

These issues will affect the actual purchase of herbal products, by understanding that the buying pattern will help entrepreneurs in determining an effective marketing strategy (Kim \& Chung, 2011) and also to ensure the continuity of business sustainability (Carneiro et al., 2005; Ibrahim \& Najjar, 2008; Paul \& Rana, 2012).

\section{Literature Review}

\subsection{Product Safety}

The issue related to the safety of herbal product is increasing, this is because the herbs may cause toxicity and serious adverse. In order to protect the safety of customers, the quality of herbal products need to be determine (Fu et al., 2009). According to Grunert (2005), product safety is customers' believe on how safe is the product. It is also associated with customers' concerns over the safety of the product in the manufacturing process (Michaelidou \& Hassan, 2008). Previous studies have discussed issues related to toxicity and safety of herbal product, resulting from the reaction of toxicity effect of the used herbal product (Ang et al., 2003, 2005). However the evidence on issues of safety, efficiency, and concerns toward the herbal product is still low (Barnes, 2003; Fu et al., 2009). Product safety plays an important role in defining whether a product is safe to be purchased or used (Chaudhuri \& Holbrook, 2001; Lodorfos et al., 2006). The safety of the product is considered as an important aspect in assessing quality (Magkos et al., 2006). A study by Shaharudin et al. (2010) on product safety found that it had affected the intention to buy. Meanwhile, attitude toward product safety was found to influence consumers in making the assumption about the importance of product safety (De Silva \& Sandika, 2011). The finding of Michaelidou dan Hassan (2008) indicated that product safety is an important factor that shape consumer's attitude.

\subsection{Perceived Risk}

Perceived risk is the uncertainty when customer cannot predict the impact of purchase decisions and it can explain the behavior where users often make mistakes and maximize their usage (Mitchell, 1999). In general, perceived risk is the feeling/expectations on unpleasant consequences associated with the variety of risks such as financial, physical, psychological, social, and time (Stephen \& Godwin, 2009). There are certain studies on efficacy and risks found that herbal product is less effective and risky compared to conventional medicine (Barnes, 2003; Brienza et al., 2002; Dergal et al., 2002). Customers believe that herbal products are natural, safe, and can be used without special attention (Ching, Zakaria, Paimin, \& Jalalian, 2013; Coutino, 2009; Cuzzolin et al., 2006; Facchinetti et al., 2012; Rotblatt, 1999; Stenton et al., 2001). However customers need to get more detailed information on the risks and benefits of the herbal product if they want to use them safely and effectively (Lynch \& Berry, 2007).

\subsection{Intention}

Fishbein and Ajzen (1975) in the theory of planned behavior described intention as a determinant of behavior, where intention is influence by three construct: attitude toward the behavior, subjective norms, and behavioral control. Intention refer to the expression during decision making process that 
depends on the attitudes and beliefs of the product (Ajzen \& Fishbein, 1980; Ajzen, 1991; Fishbein \& Ajzen, 1975). Clear intention plays an important role to human actions, however, some studies have revealed that there were difficulties in translating intentions and actual behavior (Ajzen, 2001). Therefore, purchase intention is seen as an important concept and widely used to predict the behavior of the actual purchase (Armstrong et al., 2000; Chen et al., 2012; Qing et al., 2012; Tsiotsou, 2006).

\subsection{Actual Purchase}

Actual purchase has long been of interest to researchers. Knowledge regarding actual purchase will help researchers understand the needs and wants of customers. Thus, the data obtained from the actual purchase can help to identify the marketing strategy (Kim \& Chung, 2011), customer satisfaction, and to ensure the continuity of the business (Carneiro et al., 2005; Ibrahim \& Najjar, 2008; Paul \& Rana, 2012). Certain studies found that actual purchase is complex and vary by segment (Chiang et al., 2010; Shafiq et al., 2011).

\section{Sample and procedures}

The data in this study was collected through mall intercept survey at six various states in Malaysia. The survey included measures of actual buying, buying intention, product safety, and perceived risk. A total of 576 questionnaires were distributed, but only 473 were returned representing a total of $82 \%$ response rate. Out of 473 respondents, $64.3 \%$ is dominated by female, while male accounted for $35.7 \%$ of total response. The distribution of respondents was dominated by Malays (55.8\%), followed by Chinese (28.8\%), Indian (15.9\%), and others had .2\%.

\section{Measures}

To measure the constructs of product safety, this study used four items adapted from three sources (de Jonge et al., 2007; Michaelidou \& Hassan, 2008; Rimal, 2005). Perception of risk is measured using five items adapted from three sources (Forsythe et al., 2006; Huy Tuu et al., 2010; Liu et al., 2013; Lynch \& Berry, 2007). In assessing the intention of buying, this study used four items adapted from three sources (Chaudhuri \& Holbrook, 2001; Conner et al., 2001; Jaafar et al., 2012). The actual purchase is measured using four items adapted from two sources (Chaudhuri \& Holbrook, 2001; Hassan, 2011). This study used seven point Likert scale ranging $1=$ strongly disagree to $7=$ strongly agree. Furthermore, the use the above source scale is justified as it has been found to be reliable and reached acceptable alpha coefficients of more than 0.70 (Nunnally, 1978)

\section{Result}

Before proceeding to the regression analysis, several assumptions need to be met: i) missing values ii) assumption of outliers, iii) normality assumption, and iv) Multicollinearity assumption (Hair et al., 2010; Tabachnick \& Fidell, 2007). In particular, all data were screened for missing values using SPSS. No missing data was found. Next, multivariate outliers were checked and thirty two items were detected as having outliers. All items in the dataset were screened to ensure that normality assumption was not violated.

\subsection{Measurement Model}

In order to ensure the construct validity, we followed a two-step modeling approach as suggested by Hair et al. (2014). At first, convergent validity and reliability were assessed, followed by the discriminant validity, then internal consistency reliability as shown in Table 1 and Table 2 respectively. As a rule of thumb, construct validity is ascertained if the loadings are greater than 0.7 , composite reliability is greater than 0.7 , average variance extracted is greater than 0.5 , and Cronbach's alpha is greater than 0.7 
Table 1

Results of measurement model

\begin{tabular}{|c|c|c|c|c|c|}
\hline Latent Variable & Items & Loading & Average variance extracted & Composite Reliability & Cronbach's Alpha \\
\hline \multirow{4}{*}{ Actual Buying } & BS56 & 0.836 & \multirow{4}{*}{0.712} & \multirow{4}{*}{0.908} & \multirow{4}{*}{0.865} \\
\hline & BS57 & 0.879 & & & \\
\hline & BS58 & 0.818 & & & \\
\hline & BS59 & 0.841 & & & \\
\hline \multirow{4}{*}{ Intention } & N54 & 0.815 & \multirow{4}{*}{0.554} & \multirow{4}{*}{0.830} & \multirow{4}{*}{0.725} \\
\hline & N55 & 0.852 & & & \\
\hline & N9 & 0.691 & & & \\
\hline & N6 & 0.590 & & & \\
\hline \multirow{5}{*}{ Perceived Risk } & PR31 & 0.945 & \multirow{5}{*}{0.762} & \multirow{5}{*}{0.941} & \multirow{5}{*}{0.928} \\
\hline & PR32 & 0.935 & & & \\
\hline & PR33 & 0.806 & & & \\
\hline & PR34 & 0.876 & & & \\
\hline & PR35 & 0.791 & & & \\
\hline \multirow{4}{*}{ Product Safety } & KP50 & 0.834 & \multirow{4}{*}{0.835} & \multirow{4}{*}{0.953} & \multirow{4}{*}{0.935} \\
\hline & KP51 & 0.924 & & & \\
\hline & KP52 & 0.952 & & & \\
\hline & KP53 & 0.940 & & & \\
\hline
\end{tabular}

We also conducted the discriminant validity following Fornell and Larcker (1981) recommendations. On the basis of their recommendations, the average variance shared between each construct and its measures should exceed the variance shared between the construct and other constructs (Fornell \& Larcker, 1981).

Table 2

Discriminant validity of constructs

\begin{tabular}{ccccc}
\hline Latent variable & Actual Buying & Intention & Perceived Risk & Product Safety \\
\hline Actual Buying & $\mathbf{0 . 8 4 4}$ & & & \\
Intention & 0.693 & $\mathbf{0 . 7 4 4}$ & & \\
Perceived Risk & -0.150 & -0.158 & $\mathbf{0 . 8 7 3}$ & $\mathbf{0 . 9 1 4}$ \\
\hline Product Safety & -0.189 & -0.160 & 0.846 & \\
\hline Note: Diagonals (bold face) represent the square root of the average variance extracted while the other entries represent the correlations.
\end{tabular}

As shown in Table 2, the correlations for each construct is less than the square root of the average variance extracted suggesting adequate discriminant validity of the constructs (Hair et al., 2010).

\subsection{Structural Model}

Following the measurement model next was the structural model. The results are presented in Table 3 and Fig. 2 . The $\mathrm{R}^{2}$ values of 0.48 which suggest that the modeled variables can explain $48 \%$ of variance in actual buying.

Table 3

Path coefficients and hypothesis testing

\begin{tabular}{cccccc}
\hline Hypothesis & Relation & Beta & Standard error & T-statistics & Findings \\
\hline H1 & I $\rightarrow$ AB & 0.692 & 0.031 & $22.487^{* * *}$ & Supported \\
H2 & PR* PS $\rightarrow$ I & 0.065 & 0.031 & $2.123^{* *}$ & Moderated \\
H3 & PR $\rightarrow$ I & -0.072 & 0.095 & 0.759 & Not Supported \\
H4 & PS $\rightarrow$ I & -0.036 & 0.114 & 0.317 & Not Supported \\
\hline
\end{tabular}

Actual Buying $\left(\mathrm{R}^{2}\right)=48 \%$

Note: $* * * \mathrm{p}<0.01, * * \mathrm{p}<0.05$ 


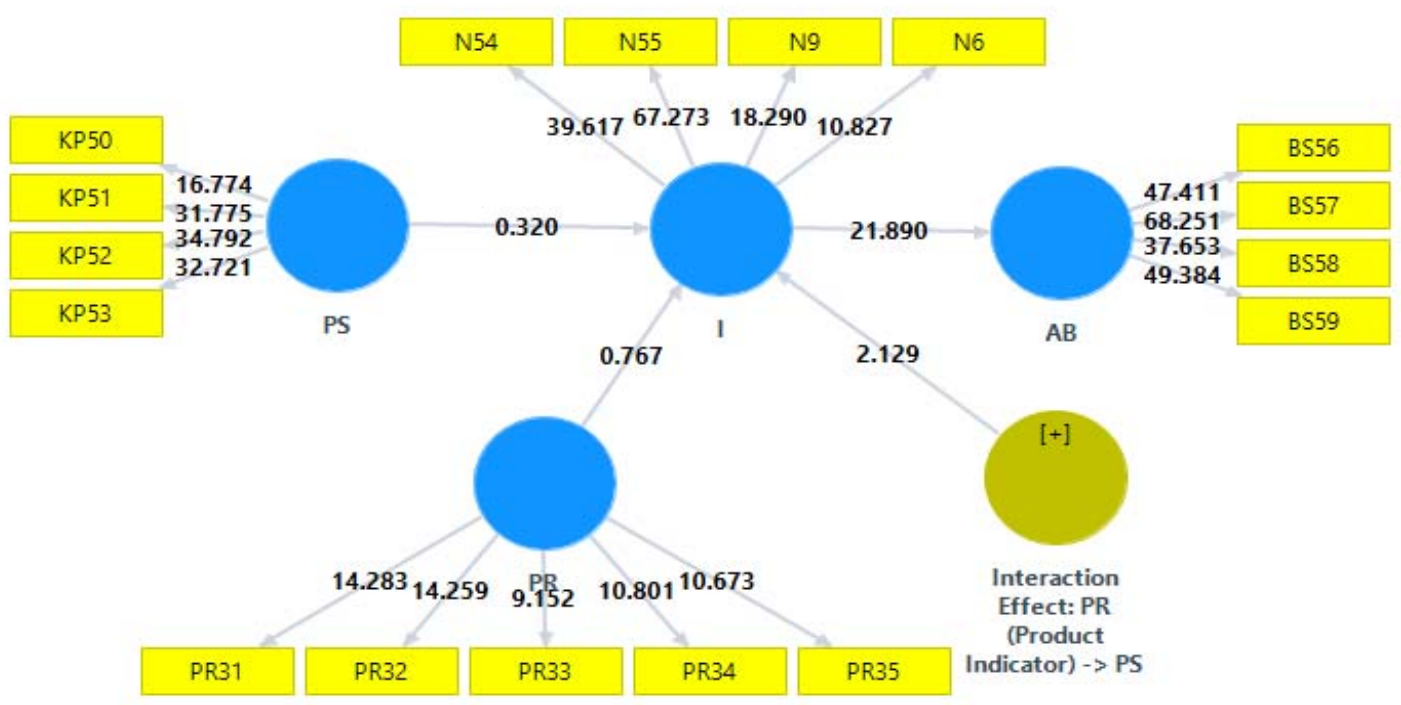

Fig. 2. Structural Model Analysis output

\section{Discussion}

This study investigated the influence of perceived risk on the relation between product safety and buying intention of herbal product in Malaysia. The result showed that buying intention was positively related to actual buying. This finding is consistent with the result of previous research (e.g. Mohammed Esmail Al-Ekam et al., 2012). The other finding of this study indicated that perceived risk moderate the relationship between product safety and buying intention. The result demonstrates that customers who have low perceived risk will generate higher intention to buy the product. The finding of this study also revealed that perceived risk was not a significant predictor of buying intention and product safety, and this finding is found to be similar with previous study (Michaelidou \& Hassan, 2008). The path relationship of perceived risk to buying intention was found insignificant and is in line with previous research (Shivraj \& Vikas, 2004).

\section{References}

Abdullah, N., \& Salleh, S. (2010). Factors related to the use of herbal products and derivatives from consumers' perspective in Kota Kinabalu, Sabah: An Initial Study. Sosiohumanika, 3(1), 143-154.

Ajzen, I. (1991). The theory of planned behavior. Organizational Behavior and Human Decision Processes, 50(2), 179-211. doi:10.1016/0749-5978(91)90020-T

Ajzen, I. (2001). Nature and operation of attitude. Annual Reviews Psychology, 52, 27-58.

Ajzen, I., \& Fishbein, M. (1980). Understanding attituted and predicting social behavior. Englewood Cliffs, NJ: Prentice Hall.

Ang, H.-H., Lee, E. L., \& Kiyoshi, M. (2003). Analysis of lead content in herbal preparations in Malaysia. Human \& Experimental Toxicology, 22, 445-451.

Ang, H.-H., Lee, K.-L., \& Kiyoshi, M. (2005). Determination of lead in Smilax Luzonensis herbal preparations in Malaysia. International Journal of Toxicology, 24, 165-171.

Armstrong, J. S., Morwitz, V. G., \& Kumar, V. (2000). Sales forecasts for existing consumer products and services: Do purchase intentions contribute to accuracy? International Journal of Forecasting, 16, 383-397.

Astin, J. A. (1998). Why patients use alternative medicine results of a national study. American Medical Association, 279(19), 1548-1553.

Balammal, G., Babu, M. S., \& Reddy, P. J. (2012). Analysis of herbal medicines by modern chromatographic techniques. Pharmaceutical Research, 3(1), 50-63. 
Barnes, J. (2003). Quality, efficacy and safety of complementary medicines: fashions, facts and the future. Part II: Efficacy and Safety. British Journal of Clinical Pharmacology, 55(4), 331-340.

Bent, S. (2008). Herbal medicine in the United States: review of efficacy, safety, and regulation: grand rounds at University of California, San Francisco Medical Center. Journal of General Internal Medicine, 23(6), 854-859.

Bouldin, S., Smith, M. C., Garner, D. D., Szeinbach, S. L., Frate, D. A., \& Croom, E. M. (1999). Pharmacy and herbal medicine in the US. Social Science \& Medicine, 49, 279-89.

Boullata, J. I., \& Nace, A. M. (2000). Safety issues with herbal medicine. Pharmacotherapy, 20(3), 257-69.

Brienza, R. S., Stein, M. D., \& Fagan, M. J. (2002). Delay in obtaining conventional healthcare by famale internal medicine patients who use herbal therapies. Journal of Women Health \& GenderBased Medicine, 11(1), 79-87.

Carneiro, J. D. D. S. J. C. S., Minim, V. P. R., Deliza, R., Silva, C. H. O., \& Leão, F. P. (2005). Labelling effects on consumer intention to purchase for soybean oil. Food Quality and Preference, 16(3), 275282.

Chaudhuri, A., \& Holbrook, M. B. (2001). The chain of effects from brand trust and brand affect to brand performance: The role of brand loyalty. Journal of Marketing, 65(2).

Chen, C.-C., Chen, P.-K., \& Huang, C.-E. (2012). Brands and consumer behavior. Social Behavior and Personality, 40(554), 105-114.

Chiang, D.-A., Wang, Y.-H., \& Chen, S.-P. (2010). Analysis on repeat-buying patterns. KnowledgeBased Systems, 23(8), 757-768.

Ching, S. M., Zakaria, Z. A., Paimin, F., \& Jalalian, M. (2013). Complementary alternative medicine use among patients with type 2 diabetes mellitus in the primary care setting : a cross-sectional study in. BMC Complementary and Alternative Medicine, 13(148).

Conner, M., Kirk, S. F., Cade, J. E., \& Barrett, J. H. (2001). Why do women use dietary supplements? The use of the theory of planned behaviour to explore beliefs about their use. Social Science \& Medicine, 52(4), 621-33.

Coutino, M. (2009). Legal and regulatory review The regulation of herbal medicine. Journal of Management \& Marketing, 2(4), 442-447.

Cuzzolin, L., Zaffani, S., \& Benoni, G. (2006). Safety implications regarding use of phytomedicines. European Journal of Clinical Pharmacology, 62(1), 37-42.

De Jonge, J., van Trijp, H., Jan Renes, R., \& Frewer, L. (2007). Understanding consumer confidence in the safety of food: Its two-dimensional structure and determinants. Risk Analysis, 27(3), 729740.

De Silva, P. H. G. J., \& Sandika, A. L. (2011). Quality standard labeling information on meat packs demanded by consumers and relationship with purchasing motives. Journal of Agricultural Science, $6(2), 1-16$.

Dergal, J. M., Gold, J. L., Laxer, D. A., Lee, M. S. W., Binns, M. A., Lanctôt, K. L., ... Rochon, P. A. (2002). Potential interactions between herbal medicines and conventional drug therapies used by older adults attending a memory clinic. Drugs \& Aging, 19(11), 879-886.

Facchinetti, F., Pedrielli, G., Benoni, G., Joppi, M., Verlato, G., Dante, G., ... Cuzzolin, L. (2012). Herbal supplements in pregnancy: Unexpected results from a multicentre study. Human Reproduction, 27(11), 3161-3167.

Fishbein, M., \& Ajzen, I. (1975). Belief, Attitude, Intention and Behaviour : The Introduction to Theory and Research (pp. 1-520). Addison-Wesley Publushing Company, Inc.

Fornell, C., \& Larcker, D. F. (1981). Evaluating structural equation models with unobservable variable and measuarement error. Journal of Marketing Research, 18(1), 39-50.

Forsythe, S., Liu, C., Shannon, D., \& Gardner, L. C. (2006). Development of a scale to measure the perceived benefits and risks of online shopping. Journal of Interactive Marketing, 20(2), 55-75.

Fu, P. P., Chiang, H.-M., Xia, Q., Chen, T., Chen, B. H., Yin, J.-J., ... Yu, H. (2009). Quality assurance and safety of herbal dietary supplements. Journal of Enviromental Science and Health, 27(2), 91119. 
Grunert, K. G. (2005). Food quality and safety: consumer perception and demand. European Review of Agricultural Economics, 32(3), 369-391.

Hair, J. F. J., Black, W. C., Babin, B., \& Anderson, R. E. (2010). Multivariate Data Analysis A Global Perspective (Seventh Ed., pp. 1-800). Prentice Hall.

Hair, J. F. J., Hult, G. T. M., Ringle, C. M., \& Sarstedt, M. (2014). A Primer On Partial Least Squares Structure Equation Modeling (PLS-SEM) (pp. 1-307). Sage Publications Inc.

Hassali, M. A., Khan, T. M., Shafie, A. A., \& Nazir, M. (2009). Public knowledge about herbal beverages in penang, Malaysia. Australasian Medical Journal, 1(6), 1-11.

Hassan, S. H. (2011). Managing conflicting values in functional food consumption: the Malaysian experience. British Food Journal, 113(8), 1045-1059.

Huy Tuu, H., Ottar Olsen, S., \& Thi Thuy Linh, P. (2010). The moderator effect of perceived risk, objective knowledge and certainty in the satisfaction-loyalty relationship. Journal of Consumer Marketing, (July), 1-40.

Ibrahim, H., \& Najjar, F. (2008). Assessing the effects of self-congruity, Attitudes and customer satisfaction on customer behavioural intentions in retail environment. Marketing Intelligence \& Planning, 26(2), 207-227.

Jaafar, S. N., Pan, E. L., \& Mohamed@Naba, M. (2012). Customers' perceptions, attitude and purchase intention towards privete label food products in Malaysia. Asian Journal of Business and Management Sciences, 2(8), 73-90.

Jamal, J. A. (2006). Malay traditional medicine an overview of scientific and technological progress. Tech Monitor, (Nov/Dec), 37-49.

Karim, A., Adzahan, M., Ab Karim, M. ., Nasouddin, S. ., Othman, M., Mohd Adzahan, N., \& Hussin, S. . (2011). Consumers' knowledge and perception towards Melicope ptelefolia ( Daun Tenggek Burung ): A preliminary qualitative study. International Food Re, 18(4), 1481-1488.

Kim, H. Y., \& Chung, J.-E. (2011). Consumer purchase intention for organic personal care products. Journal of Consumer Marketing, 28(1), 40-47.

Liu, M. T., Brock, J. L., Shi, G. C., Chu, R., \& Tseng, T.-H. (2013). Perceived benefits, perceived risk, and trust: Influences on consumers' group buying behaviour. Asia Pacific Journal of Marketing and Logistics, 25(2), 225-248.

Lodorfos, G. N., Mulvana, K. L., \& Temperley, J. (2006). Consumer behaviour: Experience, price, trust and subjective norms in the OTC pharmaceutical market. Innovative Marketing, 2(3), 41-66.

Lynch, N., \& Berry, D. (2007). Differences in perceived risks and benefits of herbal , over-the-counter conventional, and prescribed conventional, medicines, and the implications of this for the safe and effective use of herbal products. Complementary Therapies in Medicine, 15, 84-91.

Magkos, F., Arvaniti, F., \& Zampelas, A. (2006). Organic food: Buying more safety or just peace of mind? A critical review of the literature. Critical Reviews in Food Science and Nutrition, 46(1), 2356.

Michaelidou, N., \& Hassan, L. M. (2008). The role of health consciousness, food safety concern and ethical identity on attitudes and intentions towards organic food. Internal Journal of Consumer Studies, 32, 163-170.

Mitchell, V.-W. (1999). Consumer perceived risk: Conceptualisations and models. European Journal of Marketing, 33(1/2), 163-195.

Mohammed Esmail Al-Ekam, J., Kamariah Nik Mat, N., Md. Salleh, S., Mohammed Umar, H., Ewugi, M., Salameh, A., ... Nik Mat, N. K. (2012). Determining the antecedents of actual purchase of local product brand in Yemen. American Journal of Economics, June(Special Isue), 97-100.

Nunnally, J. C. (1978). Psychometric Theory (2nd Editio.). New York: McGraw-Hill.

Pal, S. K. (2002). Complementary and alternative medicine: An overview. Current Science, 82(5), 518-524.

Paul, J., \& Rana, J. (2012). Consumer behavior and purchase intention for organic food. Journal of Consumer Marketing, 29(6), 412-422. 
Qing, P., Lobo, A., \& Chongguang, L. (2012). The impact of lifestyle and ethnocentrism on consumers' purchase intentions of fresh fruit in China. Journal of Consumer Marketing, 29(1), 43-51. doi:10.1108/07363761211193037

Raghavendra, H., Yogesh, H., Gopalakrishna, B., Chandrashekhar, V., Sathis Kumar, B., \& Kumar, V. (2009). An overview of herbal medicine. International Journal of Pharmaceutical Sciences, 1(1), $1-20$.

Rimal, A. (2005). Meat labels: Consumer attitude and meat consumption pattern. International Journal of Consumer Studies, 29, 47-54.

Rotblatt, M. D. (1999). Herbal medicine: A practical guide to safety and quality assurance. The Western Journal of Medicine, 171, 172-175.

Saad, B., Azaizeh, H., Abu-Hijleh, G., \& Said, O. (2006). Safety of traditional Arab herbal medicine. Complementary and Alternative Medicine, 3(4), 433-439.

Sahoo, N., Manchikanti, P., \& Dey, S. (2010). Fitoterapia herbal drugs : Standards and regulation. Fitoterapia, 81(6), 462-471.

Saokaew, S., Suwankesawong, W., \& Permsuwan, U. (2011). Safety of herbal products in Thailand: An analysis of reports in the Thai health product vigilance center database from 2000 to 2008. Drug Sat, 34(4), 339-351.

Shafiq, R., Raza, I., \& Zia-ur-rehman, M. (2011). Analysis of the factors affecting customers' purchase intention: The mediating role of perceived value. African Journal of Business Management, 5(26), $10577-10585$.

Shaharudin, M. R., Pani, J. J., Wan Mansor, S., Jamel Elias, S., \& Malaisie, E. N. (2010). Factors affecting purchase intention of organic food in Malaysia's Kedah atate. Cross-Caltural Communication, 6(2), 105-116.

Shivraj, K., \& Vikas, J. (2004). Relationship between risk and intention to purchase in an online context: Role of gender and product category. In ECIS 2004 Proceedings (p. Paper 95).

Stenton, S. B., Bungard, T. J., \& Ackman, M. L. (2001). Interactions between warfarin and herbal products, minerals and vitamins : A pharmacist's guide. Canadian Journal of Hospital Pharmacy, 54(3), 186-192.

Stephen, A., \& Godwin, S. A. (2009). The concept and measurement of perceived risk: A marketing application in the context of the new product development process. In Proceddings of ASBBS (Vol. 16, pp. 1-9).

Tabachnick, B. G., \& Fidell, L. S. (2007). Using Multivariate Statistics (pp. 1-980). Boston, MA: Pearson Education Inc.

Tsiotsou, R. (2006). The role of perceived product quality and overall satisfaction on purchase intentions. International Journal of Consumer Studies, 30(2), 207-217.

WHO. (2011). The world medicines situation 2011. Journal of alternative and complementary medicine (New York, N.Y.) (Vol. 16, pp. 1-12).

Zaffani, S., Cuzzolin, L., \& Benoni, G. (2006). Herbal products : behaviors and beliefs among Italian women. Pharmacoepidemiology and Drug Safety, 15, 354-359. 